\title{
Dyscyplina na lekcji - czy jest możliwa bez kar i nagród?
}

\begin{abstract}
Streszczenie
Nauczyciele, ucząc dzieci, często mierzą się z problemem dyscypliny na zajęciach. Uczniowie nie zawsze chcą wykonywać polecenia, wdają się w rozmowy z kolegami podczas lekcji czy bawią się przedmiotami, które mają pod ręką. Wielokrotnie tego typu zachowania wprowadzają chaos i dezorganizują pracę całej grupy. Aby temu zaradzić i zmotywować uczniów do nauki, wielu nauczycieli decyduje się na wprowadzenie systemu kar i nagród. Pojawiają się plusy i minusy, dodatkowe oceny, a także nagrody rzeczowe, na przykład pieczątki, naklejki czy słodycze. Poprawa w zachowaniu uczniów zwykle jest widoczna, lecz równie często jest ona krótkotrwała. Systemy motywacyjne mają też inne liczne wady. Artykuł opisuje problem dyscypliny w grupach dziecięcych, a także systemy motywacyjne wraz z ich pozytywnymi i negatywnymi skutkami. Przedstawione są również alternatywne sposoby utrzymania dyscypliny na zajęciach i budowania motywacji uczniów.
\end{abstract}

Slowa kluczowe: wychowanie przedszkolne i wczesnoszkolne, uczenie małych dzieci, języki obce, motywacja, kary i nagrody, dyscyplina

\section{Wstęp}

Ucząc dzieci języków obcych, nauczyciele stają przed wieloma wymaganiami i wyzwaniami. Oczekuje się od nich przede wszystkim odpowiedniego wykształcenia akademickiego, bardzo dobrej znajomości języka obcego oraz umiejętności dydaktycznych i pedagogicznych, które, mówiąc ogólnie, odnoszą się do umiejętności nauczania i organizowania nauki. Poza formalnymi kwalifikacjami dobry nauczyciel młodszych grup wykazuje się również wiedzą na temat rozwoju dziecka i wynikających z niego możliwości i ograniczeń, a także posiada zdolności interakcyjne, odnoszące się do nawiązywania kontaktu z uczniem. Często pozytywne nastawienie ucznia do nauki wynika właśnie z sympatii do nauczyciela, dlatego relacje nauczyciel-uczeń są w tej grupie wiekowej wyjątkowo ważne. 
Niejednokrotnie jednak kwestia dobrej współpracy z uczniem i odpowiedniej dyscypliny podczas zajęć staje się problematyczna. Pomimo ogromnej wiedzy i największych chęci nauczyciel nie poprowadzi dobrej lekcji, jeśli uczniowie nie będą mieli ochoty go słuchać. Aby utrzymać dyscyplinę w klasie i zmotywować dzieci do aktywnego udziału w zajęciach, nauczyciele często sięgają po tzw. systemy motywacyjne. Są to systemy kar i nagród, które mogą przyjmować różne formy, takie jak plusy i minusy, uśmiechnięte i smutne buźki, oceny czy nagrody rzeczowe. Często przynoszą one zakładany efekt, jednak bywa on krótkotrwały. Systemy motywacyjne mają też inne liczne wady. Celem poniższego artykułu jest opisanie problemu dyscypliny na lekcji języka obcego w grupach dziecięcych, a w szczególności w grupach przedszkolnych i wczesnoszkolnych, oraz przedstawienie idei systemów motywacyjnych, a także alternatywnych sposobów radzenia sobie z problematycznym zachowaniem uczniów.

\section{Dyscyplina}

Komorowska (2005) definiuje utrzymanie dyscypliny na lekcji jako „niedopuszczenie do niepotrzebnej zmiany scenariusza lekcji i uniemożliwienie uczniom [...] sprowokowania zmiany tematu wypowiedzi nauczyciela z przedmiotu pracy na zachowanie uczniów”. Celem nauczyciela podczas lekcji jest realizacja planu nauczania, co staje się niewykonalne, gdy w klasie brakuje porządku i uwagi.

Problemy z utrzymaniem dyscypliny na lekcji są szczególnie widoczne w grupach dziecięcych, gdzie uczniowie nie potrafią zbyt długo utrzymać koncentracji i potrzebują dużo ruchu. Niepożądane zachowania uczniów prowadzą często do chaosu i dezorganizacji pracy. Wprowadzają również negatywną atmosferę i skutecznie demotywują uczniów do pracy. Bez wątpienia przyczyniają się także do zniechęcenia i frustracji wśród nauczycieli.

Do najczęstszych problemów w grupach dziecięcych należy wysoki poziom hałasu oraz nadruchliwość dzieci. Mali uczniowie lubią zmieniać miejsca, przechadzać się po klasie oraz bawić się przedmiotami, które mają pod ręką. Nie zawsze potrafią powstrzymać się od rozmów z kolegami i komentarzy na temat przebiegu lekcji. Nie mają oporów, aby wprost powiedzieć nauczycielowi, że lekcja jest nudna. Lubią zagadywać nauczyciela i opowiadać różne historie. Zdarza się także brak zainteresowania lekcją i unikanie udziału w różnych aktywnościach, a czasem również niestosowanie się do poleceń nauczyciela. Problematyczne może być również częste wychodzenie do toalety, które spowodowane jest jedynie chęcią wyjścia z sali.

Wyraźnie trzeba zaznaczyć, że większość opisanych powyżej zachowań to naturalne reakcje dzieci, które wynikają z ich ścieżki rozwojowej oraz naturalnych potrzeb, a nie ze złośliwości i chęci utrudnienia pracy nauczycielowi. Ucząc kilkuletnie dzieci, warto wziąć pod uwagę to, że potrzebują one dużo ruchu oraz częstej zmiany aktywności. Nie są jeszcze w pełni zdolne kontrolować swojej uwagi, stąd częste dygresje w mało odpowiednich momentach. Komentarze dotyczące atrakcyjności lekcji należy natomiast traktować jako szczerą reakcję i sygnał do zmiany aktywności, a nie jako uwagę mającą sprawić przykrość nauczycielowi. Opisane zachowania, choć w dużej mierze w pełni 
naturalne, stają się problematyczne, gdy pojawiają się często i dotyczą znacznej części grupy. Konieczne wydaje się znalezienie sposobu ich kontrolowania i opanowania.

\section{Systemy motywacyjne}

Aby ograniczyć liczbę zachowań niepożądanych podczas lekcji, nauczyciele często stosują różnego rodzaju systemy motywacyjne, których założeniem jest nagradzanie zachowań odpowiednich oraz karanie tych nieodpowiednich. Należą do nich między innymi oceny za zachowanie, plusy i minusy, punkty, pieczątki, nagrody rzeczowe (np. naklejki czy słodycze) lub ich brak, pozytywne i negatywne symbole (np. buźki, słoneczka, chmurki) czy uwagi pisane do rodziców. Zależnie od wyboru nauczyciela system motywacyjny może zakładać kary i nagrody dla pojedynczych dzieci lub dla całej grupy. W drugim przypadku mamy do czynienia z odpowiedzialnością zbiorową. Wprowadzenie systemu motywacyjnego powinno być poprzedzone ustaleniem zasad pracy oraz oczekiwań nauczyciela wobec uczniów.

Konsekwencje stosowania tego typu motywacji bywają różne. Do pozytywnych skutków można zaliczyć to, że niejednokrotnie zachowanie faktycznie się poprawia, ponieważ uczniom zależy na nagrodzie bądź boją się kary. Dzieci stają się bardziej uważne i starają się kontrolować swoje reakcje. Często pilnują nie tylko siebie, ale też innych, szczególnie gdy stosowana jest odpowiedzialność zbiorowa. Bez wątpienia odczuwają również radość i dumę z otrzymanej nagrody. Śpiewak (2015) zauważa, że motywacja zewnętrzna w przypadku dzieci jest do pewnego stopnia potrzebna i przydatna, ponieważ kilkuletnim uczniom trudno jest znaleźć wewnętrzny impuls do używania języka obcego w sytuacjach, w których bez problemu porozumieliby się w języku polskim. Rozsądne systemy nagród uatrakcyjniają lekcję i zachęcają do nauki.

Z drugiej strony obserwowany efekt bywa dość krótkotrwały, gdyż dzieci szybko przyzwyczajają się do systemu i mogą po jakimś czasie odczuwać znudzenie. Regularnie otrzymywane kary i nagrody przestają być czymś wyjątkowym i tracą swoje znaczenie. Po pewnym czasie nagrody przestają być doceniane, a kary zaczynają być lekceważone. W związku z tym, że najczęściej trafiają one wciąż do tych samych osób, uczniowie zostają obsadzani w ustalonych rolach w grupie, na przykład klasowego rozrabiaki lub wzorowej uczennicy. Tego typu „łatki” mogą rzutować na relacje między dziećmi oraz ich samoocenę (Dörnyei, Murphey, 2003). Jak wcześniej wspomniano, systemy kar i nagród zwiększają motywację zewnętrzną dzieci, w związku z czym uczą je nauki i pracy w zamian za wymierne korzyści. Ideałem natomiast byłoby wspieranie motywacji wewnętrznej uczniów, dzięki której dzieci chcą się uczyć i pracować dla siebie, z wewnętrznej potrzeby. Różnica pomiędzy motywacją wewnętrzną i zewnętrzną wyraźnie ujęta jest w poniższym cytacie: „Uczeń dostaje przekaz: «Musisz się tego nauczyć nie dlatego, że to jest ciekawe, ważne czy przydatne w życiu, ale dlatego, że jest w programie i może pojawić się w teście»" (Żylińska, 2013). W przypadku dyscypliny oznacza to, że uczeń stara się aktywnie brać udział w zajęciach nie dlatego, że są one dla niego ciekawe i atrakcyjne, ale dla nagrody, którą może za to uzyskać. 


\section{Sposoby zachowania dyscypliny - zapobieganie}

Kluczem do zachowania porządku w klasie i realizacji założonych celów jest niedopuszczanie, w miarę możliwości, do pojawiania się problemów dyscyplinarnych. Zapobiegać niepożądanym zachowaniom uczniów można na różne sposoby. Przede wszystkim warto mieć realne oczekiwania dotyczące procesu i efektów uczenia najmłodszych. Kilkuletnie dzieci charakteryzują się krótkim czasem skupienia uwagi oraz naturalną skłonnością do zabawy. Nie oddzielają jeszcze czasu na zabawę od czasu na naukę. Aktywności proponowane tak małym uczniom powinny być krótkotrwałe i zróżnicowane. Warto przeplatać statyczne ćwiczenia dynamicznymi i wykorzystywać aktywności ruchowe (Rokita-Jaśkow, 2015). Nauczyciel oczekujący, że grupa przedszkolaków spędzi 45 minut lekcji w ciszy, wykonując ćwiczenia z podręcznika, jest niestety z góry skazany na niepowodzenie.

Jak podaje Komorowska (2005), ,zapewnienie atrakcyjności lekcji to oczywisty sposób skupienia i utrzymania uwagi uczniów, a więc i zagwarantowania ładu i porządku na lekcji”. Gdy aktywności wykonywane podczas zajęć są dla uczniów ciekawe i angażujące, a dodatkowo dotyczą ich zainteresowań, uczniowie nie mają czasu ani chęci zakłócać spokoju na lekcji. Ponadto najmłodsi potrzebują przewidywalnego oraz stabilnego planu zajęć z rutynowymi elementami (Szpotowicz, Szulc-Kurpaska, 2012). Dzięki wyraźnemu podziałowi lekcji na czas na dywanie i czas przy stolikach oraz zaznaczanie etapów lekcji poprzez piosenki czy rymy (np. na przywitanie czy pożegnanie) uczniowie wiedzą, czego się spodziewać i czują się bezpiecznie, co wpływa na ich zachowanie podczas lekcji.

W pracy z dziećmi wielce istotne jest również szczegółowe zaplanowanie następujących po sobie aktywności. Niekiedy zdarza się, że lekcji brakuje dynamiki i odpowiedniego tempa, a nauczyciel potrzebuje chwili, aby zastanowić się, jakie ćwiczenie powinno nastąpić. W grupie szybko pojawia się wtedy rozluźnienie, które dzieci natychmiast wykorzystują do swoich własnych celów. Warto unikać przestojów pomiędzy aktywnościami i dynamicznie je zmieniać. Dzieci powinny mieć cały czas zajęte głowy i ręce. Uczniów nadruchliwych warto zaangażować w sprawy organizacyjne, na przykład poprosić o starcie tablicy, aby zagospodarować ich nadmierną energię.

Istotną częścią zapobiegania problemom dyscyplinarnym jest ustalenie zasad panujących w klasie i konsekwentne ich przestrzeganie. Dzieci muszą otrzymać jasny sygnał, jakie zachowanie jest akceptowane, a jakie nie. Gdy sytuacja nie jest oczywista, dzieci zachowają się intuicyjnie, co nie zawsze spotka się z aprobatą nauczyciela. Uczniowie szybko wyczują też, że jego zachowanie nie pokrywa się z ustalonymi wcześniej zasadami. Jeśli poprosi on uczniów, żeby nie biegali w klasie, ponieważ mogą się przewrócić, a następnie ignoruje to, że część z nich nadal biega, to uczniowie otrzymują informację, że zasady ustalone przez nauczyciela nie są wiążące. Komunikaty przekazywane dzieciom powinny być zwięzłe i bezpośrednie, na przykład „Pozbierajcie i odłóżcie kredki. Dopiero wtedy wyjdziemy" (MacKenzie, 1996).

Jak wcześniej wspomniano, motywacja dzieci do udziału w zajęciach w dużej mierze zależy od sympatii do nauczyciela. Warto więc utrzymywać dobre relacje z uczniami, uśmiechać się i okazywać im zainteresowanie. Zdarza się, że nauczyciel wykazuje zainteresowanie uczniem dopiero wtedy, gdy ten zaczyna zaburzać spokój lekcji. Jest to 
uwaga negatywna, która utwierdza ucznia w przekonaniu, że jest to jedyny sposób, aby być w centrum uwagi i zyskać zainteresowanie nauczyciela. Ten rodzaj uwagi warto zamienić na uwagę pozytywną, czyli chwalić uczniów nawet za najmniejsze osiągnięcia i wyraźnie doceniać ich starania. Szczególnie ważne jest to w przypadku uczniów przeszkadzających w lekcji (Komorowska, 2005).

Istotne jest, aby nauczyciel pracujący z małymi dziećmi wykazywał się cierpliwością i zrozumieniem. Niepożądane zachowania uczniów nie pojawiają się bez powodu. Warto zastanowić się, skąd się biorą i pracować u przyczyny problemu. Trudności w skupieniu bądź niechęć do aktywnego udziału w zajęciach mogą wynikać ze zmęczenia, pogody czy sytuacji, która wydarzyła się przed zajęciami. Miejmy to na uwadze i starajmy się być elastyczni i zmienić typ aktywności, jeśli jest taka potrzeba. Rozpraszać dzieci mogą również hałasy z zewnątrz czy zabawki znajdujące się w sali. W przypadku poważniejszych problemów może się okazać, że uczeń nie otrzymuje wystarczającej uwagi w domu i próbuje tę uwagę zyskać w przedszkolu czy szkole.

\section{Sposoby zachowania dyscypliny - reagowanie}

Niekiedy okazuje się, że zapobieganie nie jest wystarczające i problemy z dyscypliną nadal się pojawiają. Warto wtedy skorzystać z technik utrzymania dyscypliny, proponowanych przez Komorowską (2005). Są to: techniki niewerbalne, techniki werbalne w obrębie tematyki związanej z lekcją oraz techniki werbalne związane z zachowaniem uczniów. Istotne jest to, aby stosować je w podanej kolejności i do ostatniej kategorii odwoływać się dopiero, gdy pozostałe dwie zawiodą.

W pierwszej kolejności zaleca się stosowanie technik niewerbalnych, dzięki którym nauczyciel skutecznie zyskuje uwagę ucznia, nie przerywając toku lekcji. Powinny być one wykonane szybko, aby nie odwracać uwagi reszty uczniów od tematu zajęć. Do tej kategorii należy między innymi ściszenie głosu, które jest dla ucznia niespodziewaną zmianą i przykuwa jego uwagę, oraz przerwanie wypowiedzi i zastosowanie nagłej ciszy. Ponadto można wykorzystać uciszający gest, taki jak podniesienie ręki, palec na ustach czy stukanie długopisem o ławkę. Gdy podczas lekcji przeszkadza jedno dziecko, warto podejść bliżej niego, nie komentując w żaden sposób jego zachowania, lub spróbować wejść z nim w kontakt wzrokowy. W przypadku gdy uczeń bawi się przedmiotem, można wyjąć mu go z ręki i odłożyć obok, jednocześnie kontynuując swoją wypowiedź związaną $\mathrm{z}$ tematem lekcji.

Gdy powyższe sposoby okażą się niewystarczające, zalecane jest przejście do technik werbalnych, nadal jednak nie zaburzając planu lekcji i nie komentując bezpośrednio zachowania uczniów. Głównym celem tej grupy technik jest pomoc uczniom niezdyscyplinowanym w skupieniu uwagi na temacie lekcji, a nie udowodnienie, że dziecko nie uważa i tym samym zwrócenie uwagi reszty grupy na ten fakt. Do technik werbalnych związanych z tematem lekcji należy między innymi wtrącenie imienia ucznia w tok wypowiedzi - „This is a computer, Tomek. Yes, a computer” - oraz prośba o powtórzenie - ,This is a computer. Tomek, repeat, please”. Ponadto warto włączać uczniów w tok 
lekcji poprzez zadanie prostego pytania lub poproszenie o powtórzenie odpowiedzi, która już padła wcześniej. Skutecznym sposobem reagowania na problemy z dyscypliną jest również zmiana charakteru pracy, na przykład krótka gimnastyka w języku obcym, oraz przerwanie pracy na szybkie wspólne wykonanie piosenki czy wiersza.

Opisane techniki pozwalają nauczycielowi przyciągnąć uwagę uczniów i wdrożyć ich w tok lekcji bez publicznego krytykowania i karcenia. Reszta grupy również pozostaje skupiona na lekcji i nie zostaje rozproszona przez niepożądane zachowania kolegów. Gdy sytuacja jest bardziej wymagająca, do dyspozycji nauczyciela pozostają techniki werbalne związane bezpośrednio z zachowaniem uczniów. Należy jednak pamiętać, że sięgamy po nie dopiero wtedy, gdy wspomniane wcześniej techniki zawiodą. Nie należy stosować ich od razu, gdy zaobserwujemy niepożądane zachowanie dziecka, ponieważ grozi to eskalacją konfliktu i pogorszeniem relacji nauczyciel-uczeń.

W ramach technik werbalnych związanych z zachowaniem nauczyciel krótko stwierdza fakt, na przykład „Tomek, przeszkadzasz mi” lub wyraża osobiste życzenie: „Wolałabym, żebyś nie stukał”. Można również krótko podać osobistą ocenę, na przykład „Nie podoba mi się, że bawisz się kredkami”. W tym przypadku istotne jest, aby oceniać konkretne czynności podejmowane przez ucznia, a nie jego osobę. W związku z tym lepiej jest powiedzieć „Rozmawiasz z kolegą i nie słyszysz nagrania” niż „Jesteś niegrzecznym i nieznośnym dzieckiem”. Krytyka, którą kierujemy wobec ucznia, powinna być konstruktywna. Stosując techniki werbalne, należy pamiętać, aby stanowiły one krótkie wtrącenia, po których nauczyciel natychmiast wraca do lekcji. Długie wykłady na temat zachowania uczniów rzadko się sprawdzają, a przerwy pomiędzy uwagą nauczyciela a powrotem do scenariusza lekcji zachęcają uczniów do dyskusji. Rozmowę z konkretnym dzieckiem warto przeprowadzić po zajęciach, bez świadków, aby nie czuło potrzeby popisywania się przed kolegami.

W pracy z dziećmi unikajmy przekrzykiwania ich, gdyż nie uspokaja to, a prowadzi jedynie do zwiększenia poziomu hałasu. Choć może to być czasem trudne, nie okazujmy zdenerwowania, na przykład poprzez mówienie „Piąty raz cię proszę, żebyś tego nie robił!”. Nie warto stosować pytań, które prowokują dyskusję i złośliwe odpowiedzi, takich jak „Czy ty musisz wiecznie przeszkadzać?”. Należy również unikać kontaktu $\mathrm{z}$ dyrektorem bądź rodzicem w błahych sprawach, gdyż jest to czasem odbierane jako brak umiejętności samodzielnego poradzenia sobie z problemem, co następnie podważa autorytet nauczyciela (Komorowska, 2005).

\section{Podsumowanie}

W pracy większości nauczycieli zdarzają się momenty zwątpienia i frustracji, kiedy, pomimo ogromnego wysiłku i dokładnie przygotowanej lekcji, zachowanie uczniów utrudnia realizację scenariusza. Choć systemy motywacyjne wydają się atrakcyjne i bez wątpienia mają swoje zalety, warto przemyśleć, czy ich użycie jest naprawdę konieczne. Problemom dyscyplinarnym trzeba przede wszystkim zapobiegać, a gdy jednak się pojawiają, do dyspozycji nauczyciela pozostają trzy kategorie technik reagowania, w tym techniki niewerbalne i werbalne. 
Ważne, aby dzieci były świadome tego, jakie zasady obowiązują w klasie oraz wiedziały, że nauczyciel konsekwentnie dba o ich przestrzeganie. Dużą rolę odgrywa tu szczegółowy plan lekcji, rutynowe aktywności oraz entuzjazm i uśmiech, które udzielają się uczniom. Pamiętać należy, aby chwalić dzieci nawet za najdrobniejsze osiągnięcia i zapewniać im uwagę pozytywną, a nie tylko negatywną w sytuacjach, gdy ich zachowanie odbiega od oczekiwań. Istnieje wiele kroków, które można podjąć, aby zapewnić efektywną współpracę pomiędzy nauczycielem i grupą, dzięki czemu systemy motywacyjne przestają być niezbędne. Utrzymanie dyscypliny na lekcji bez użycia kar i nagród jest zdecydowanie możliwe.

\section{Bibliografia}

Dörnyei Z., Murphey T. (2003), Group dynamics in the language classroom, Cambridge.

Komorowska H. (2005), Metodyka nauczania języków obcych, Warszawa.

MacKenzie R.J. (1996), Setting limits in the classroom. How to move beyond the classroom dance of discipline, Roseville.

Rokita-Jaśkow J. (2015), Spór o metodę, czyli jak najlepiej uczyć dzieci języków obcych, „Języki Obce w Szkole”, nr 1.

Śpiewak G. (2015), Motywacja przez małe „,m”w dydaktyce językowej najmłodszych uczniów, „Języki Obce w Szkole”, nr 1.

Szpotowicz M., Szulc-Kurpaska M. (2012), Teaching English to young learners, Warszawa. Żylińska M. (2013), Neurodydaktyka. Nauczanie i uczenie się przyjazne mózgowi, Toruń.

\section{Abstract \\ Discipline in the classroom - is it attainable without punishment and reward?}

While teaching young learners, teachers often have to face discipline problems. Students do not always follow the rules, tend to talk to their friends during a lesson or play with different toys and objects. Such behaviour leads to chaos and disruption in the classroom. In order to solve these issues and motivate children to participate in the activities, many teachers decide to use punishment and reward systems, which may take forms of pluses and minuses, extra marks, stickers, motivational stamps or sweets. There usually is some improvement in children's behaviour, but the effect is often temporary. Motivational systems have a number of other disadvantages as well. The article presents the issue of discipline in the young learner classrooms and describes the concept of motivational systems with their advantages and disadvantages. Alternative ways of maintaining discipline and enhancing students' motivation are discussed.

Keywords: children, preschool, teaching young learners, foreign languages, motivation, punishment and reward, discipline 